\title{
Effects of TiC Content on Microstructure and Mechanical Property of WC-TiC-TaC Cemented Carbides
}

\author{
GAO Jiao-Jiao, JIANG Long-Kai, SONG Jin-Peng, LIANG Guo-Xing, AN Jing, XIE Jun-Cai, CAO Lei, LV Ming
}

(Shanxi Key Laboratory of Precision Machining, School of Mechanical Engineering, Taiyuan University of Technology, Taiyuan 030024, China)

\begin{abstract}
WC-TiC-TaC cemented carbides were fabricated by hot-pressed sintering at $1600^{\circ} \mathrm{C}$. Effects of TiC content on the microstructure and mechanical properties of these cemented carbides were investigated. It was found that when TiC content was increased from $10 \mathrm{wt} \%$ to $25 \mathrm{wt} \%$, both the average grain size and the Vickers hardness increased progressively, but both the flexural strength and the fracture toughness decreased gradually. The increase of Vickers hardness was attributed to the increase of TiC content and the hardness of $\mathrm{TiC}$ was higher than that of WC. The value of the highest Vickers hardness was 19.81 GPa. This work also showed that the highest flexural strength (1147.24 MPa) was ascribed to the fine and homogeneous grains, and that the highest fracture toughness $\left(14.60 \mathrm{MPa} \cdot \mathrm{m}^{1 / 2}\right)$ was due to the intensive coupled mechanism of the fine-grain toughening, crack deflection, crack branching, crack bridging, and toughness dimples.
\end{abstract}

Key words: WC-TiC-TaC cemented carbides; hot-pressed sintering; microstructure; mechanical properties

Tungsten carbide (WC) has high hardness, high elastic modulus and good wettability by molten metals ${ }^{[1-3]}$. However, the Vickers hardness of WC (16-22 GPa) is lower than that of other carbides such as $\mathrm{TiC}(28-35 \mathrm{GPa}), \mathrm{ZrC}$ $(25.9 \mathrm{GPa})$ and $\mathrm{HfC}(26.1 \mathrm{GPa})^{[4-5]}$. In order to improve mechanical properties, physical and chemical properties of WC such as flexural strength, fracture toughness, hardness, high temperature plastic deformation resistance, high temperature oxidation resistance and wear resistance, other carbide powders and metal powders were mixed with WC powder to produce WC-based cemented carbides. WC-based cemented carbides were widely used in various applications such as tools for metal cutting, rock drilling, and roller bearings, owing to their high hardness and excellent wear resistance ${ }^{[6-8]}$. Better properties of cemented carbide tool were required to meet the need of the high speed machining ${ }^{[9-10]}$. In order to obtain high mechanical properties, refractory metal carbides and metals often were employed to improve flexural strength, fracture toughness and hardness of the WC-based cemented carbide tool.

In recent years, the refractory metal carbides including $\mathrm{VC}, \mathrm{Cr}_{3} \mathrm{C}_{2}, \mathrm{Mo}_{2} \mathrm{C}, \mathrm{NbC}$, TaC and TiC have been employed to improve the mechanical properties of WC-based cemented carbides. It was shown that $\mathrm{VC}$ and $\mathrm{Cr}_{3} \mathrm{C}_{2}$ were two typical grain growth inhibitors, which were used in producing the fine grain microstructure in WC-based cemented carbides to improve the fracture toughness ${ }^{[1-12]}$. $\mathrm{Mo}_{2} \mathrm{C}$ could refine the microstructure and improve the wettability between $\mathrm{WC}$ and $\mathrm{Ni}$, which was advantageous to the enhancement of hardness and fracture toughness ${ }^{[13-14]}$. $\mathrm{NbC}$ and $\mathrm{TaC}$ had been found to improve the wear resistance and fracture toughness ${ }^{[15-16]}$. Besides, TaC was a very effective grain growth inhibitor and could enhance the red hardness and high temperature plastic deformation resistance of cutting tools ${ }^{[14,17]}$. As an excellent candidate for components of cutting tool materials, TiC showed higher hardness, higher melting point, higher high-temperature oxidation resistance and lower density than WC, so it was employed to improve the flexural strength, hardness, fracture toughness, wear and oxidation resistance of the tool materials ${ }^{[18-21]}$.

The added metals were generally $\mathrm{Co}, \mathrm{Cr}, \mathrm{Mo}, \mathrm{Ni}$, and so on. It was widely known that $\mathrm{Co}$ as binder phase was added in the WC-based cemented carbides to obtain the unique properties such as high hardness, high Young's modulus, high strength and good wear resistance ${ }^{[22-23]}$. Literatures $^{[24-25]}$ showed that WC-based cemented carbide could obtain preferable bending strength, a microstructure 
without significant defects and a relatively good corrosion resistance when $\mathrm{Cr}$ was added in WC-based cemented carbide. Mo could improve the wettability between carbides and binder, the microstructure and the corrosion behaviour of WC-based cemented carbide ${ }^{[26-27]}$. Nickel as binder in WC-based cemented carbides had other advantages. It made the cemented carbide non-magnetic and could improve fracture toughness ${ }^{[28-30]}$.

In this paper, WC-TiC-TaC cemented carbides were prepared by hot-pressed sintering at $1600^{\circ} \mathrm{C}$ and effects of $\mathrm{TiC}$ content on the microstructure and mechanical properties of these composites were investigated.

\section{Experimental procedure}

Commercially available WC powder $(>99 \%, 1 \mu \mathrm{m}$, Shanghai Yunfu Nanotechnology Co., Ltd, China), TiC powder $(>99 \%, 1 \mu \mathrm{m}$, Shanghai Yunfu Nanotechnology Co., Ltd, China) and $\mathrm{TaC}$ powder $(>99 \%, 1 \mu \mathrm{m}$, Shanghai Xiangtian Nano Materials Co., Ltd, China) were used as the raw materials. Ni powder $(>99 \%, 1 \mu \mathrm{m}$, Shanghai Yunfu Nanotechnology Co., Ltd, China) was added as sintering aid. The compositions of WC-TiC-TaC cemented carbides were shown in Table 1.

The powders were mixed and milled for $48 \mathrm{~h}$ in a polyethylene jar with WC balls and alcohol as mediums. Then the mixed slurry was dried in vacuum and sieved by a 200-mesh sieve. The compacted powders were hot pressed for $1 \mathrm{~h}$ at $1600^{\circ} \mathrm{C}$ under $30 \mathrm{MPa}$ in vacuum $\left((1.2-2.4) \times 10^{-3} \mathrm{~Pa}\right)$. The hot pressed samples were cut into testing specimens by electrical discharge wire cutting method and the surfaces of the testing bars were polished using diamond slurries. The dimension of the specimen was $3 \mathrm{~mm} \times 4 \mathrm{~mm} \times 40 \mathrm{~mm}$.

Flexural strength was measured at a span of $30 \mathrm{~mm}$ and a crosshead speed of $0.5 \mathrm{~mm} / \mathrm{min}$ by the three-point bending test method on WD-10 electron universal tester. Fracture toughness was measured via the direct indentation method. The indenter was the Vickers DPH type and the applied static load was $196 \mathrm{~N}$ for $15 \mathrm{~s}$. Vickers hardnesswas measured on the polished surfaces using a diamond pyramid indenter under a load of $196 \mathrm{~N}$ by HV-120. At least 15 specimens were tested for each experimental condition. X-ray diffraction (XRD) was used to analyze the

Table1 Compositions of WC-TiC-TaC cemented carbides

\begin{tabular}{ccccc}
\hline Sample & WC/wt\% & TiC/wt\% & TaC/wt\% & $\mathrm{Ni} / \mathrm{wt} \%$ \\
\hline S1 & 78 & 10 & 2 & 10 \\
S2 & 73 & 15 & 2 & 10 \\
S3 & 68 & 20 & 2 & 10 \\
S4 & 63 & 25 & 2 & 10 \\
\hline
\end{tabular}

compositions of the composite. Scanning electron microscope (SEM) was used to observe the fractured surface morphologies.

\section{Results and discussion}

\subsection{Microstructure}

Figure 1 showed XRD patterns of WC-TiC-TaC cemented carbides. The major crystal phases in the composites were $\mathrm{WC}, \mathrm{TiC}$ and $\mathrm{Ni}$, which indicated that no reactions occurred during hot pressing. Relative intensity of $\mathrm{Ni}$ was weaken gradually as the $\mathrm{TiC}$ content was increased from $10 \mathrm{wt} \%$ to $25 \mathrm{wt} \%$. No clear peaks for the $\mathrm{TaC}$ were identified, which was due to a little of $\mathrm{TaC}$ in these cemented carbides.

Figure 2 exhibited the BSE micrographs of polished surfaces of WC-TiC-TaC cemented carbides. It can be found that these cemented carbides were mainly composed of the grey phase and black phase. The amount of the grey phase decreased gradually and the amount of the black phase increased progressively in Fig. 2 when the TiC content was increased from $10 \mathrm{wt} \%$ to $25 \mathrm{wt} \%$.

Figure 3 presented the EDS results for the grey phase (Point A) and the black phase (Point B) marked in Fig. 2. The grey phase was WC based on the XRD and the EDS results which revealed that the atomic ratio between $\mathrm{W}$ and $\mathrm{C}$ was about 1:1 and the total mass percentage of $\mathrm{W}$ and $\mathrm{C}$ reached to $100 \%$ in Fig. 3(a). The black phase was mainly $\mathrm{TiC}$ besides a little of $\mathrm{WC}$ and $\mathrm{TaC}$ according to the XRD and the EDS results which indicated that the atomic ratio of $\mathrm{Ti}$ and $\mathrm{C}$ was about1:1 and the total mass percentage of $\mathrm{Ti}$ and $\mathrm{C}$ nearly reached to 83\% in Fig. 3(b).

In the XRD patterns of WC-TiC-TaC cemented carbides, no obvious peaks of $\mathrm{TaC}$ were detected. For a further search of TaC, Fig. 4 showed Ta element distribution of Area $\mathrm{C}$ in Fig. 2. The distribution of $\mathrm{TaC}$ could be expressed by the distribution of Ta element, because no reaction products were found by XRD in Fig. 1.

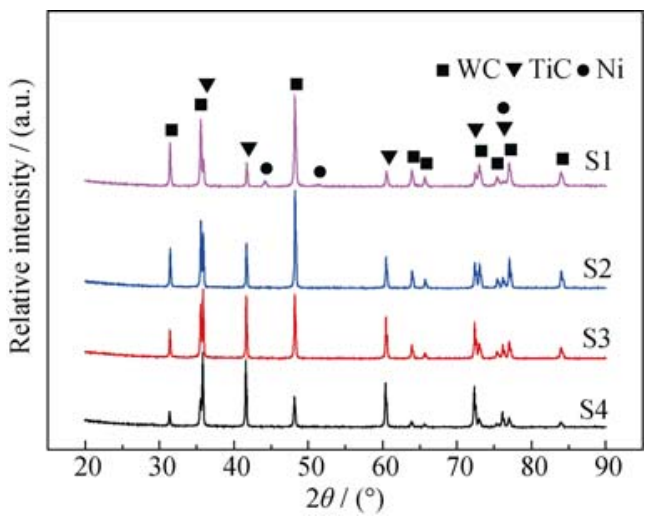

Fig. 1 XRD patterns of WC-TiC-TaC cemented carbides 

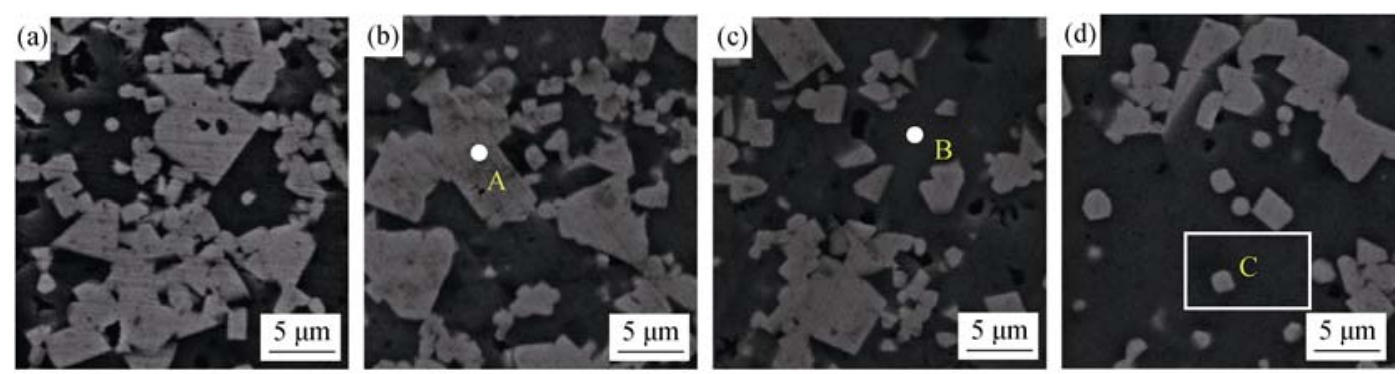

Fig. 2 BSE micrographs of polished surfaces of WC-TiC-TaC cemented carbides (a) WC-10wt\%TiC-TaC (S1); (b) WC-15wt\%TiC-TaC (S2); (c) WC-20wt\%TiC-TaC (S3); (d) WC-25wt\%TiC-TaC (S4)
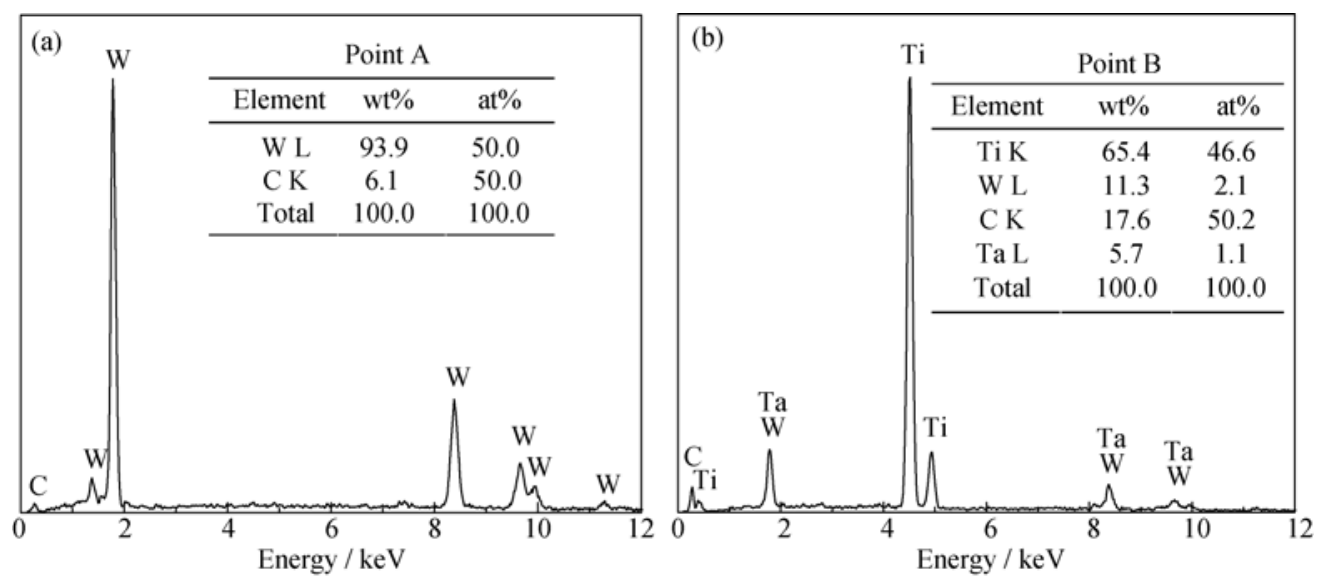

Fig. 3 EDS results corresponding to Point A and Point B in Fig. 2

Figure 5 presented the fracture morphology of WC-TiC-TaC cemented carbides. As can be seen, the grains of WC- $10 \mathrm{wt} \% \mathrm{TiC}-\mathrm{TaC}$ cemented carbide were fine and homogeneous in Fig. 5(a). More coarse grains were produced in WC-TiC-TaC cemented carbides in Fig. 5 with the increase of $\mathrm{TiC}$ content from $10 \mathrm{wt} \%$ to $25 \mathrm{wt} \%$, which resulted in the increase of the average grains size. So the order of the average granularity of these cemented carbides was $\mathrm{S} 1<\mathrm{S} 2<\mathrm{S} 3<\mathrm{S} 4$. The grains of WC-25wt\%TiC-TaC cemented carbide were mainly composed of coarse grains in Fig. 5(d). In addition, there were a lot of dimples left in the WC- $10 \mathrm{wt} \% \mathrm{TiC}-\mathrm{TaC}$ cemented carbide in Fig. 5(a). The number of the dimples of WC-TiC-TaC cemented carbides gradually dropped off in Fig. 5 when the TiC content was increased from $10 \mathrm{wt} \%$ to $25 \mathrm{wt} \%$.

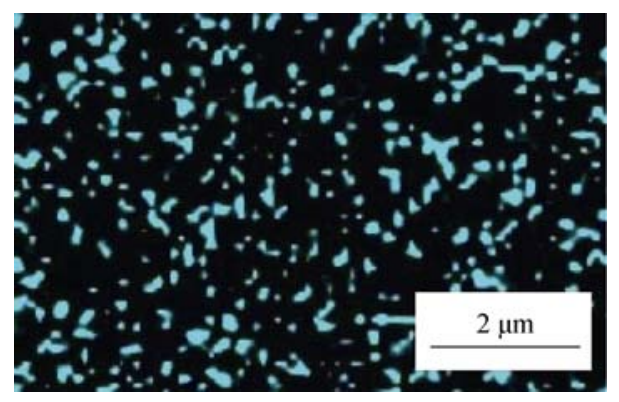

Fig. 4 Ta element distribution corresponding to Area C in Fig. 2

\subsection{Mechanical properties}

Figure 6 exhibited the influence of $\mathrm{TiC}$ content on the mechanical properties of WC-TiC-TaC cemented carbides. As can be seen, Vickers hardness had a progressive increase as the $\mathrm{TiC}$ content was increased from $10 \mathrm{wt} \%$ to $25 \mathrm{wt} \%$. The main reason was that TiC grains gradually predominated in WC-TiC-TaC cemented carbides and the ratio of $\mathrm{WC}$ grain size and $\mathrm{TiC}$ grain size decreased in Fig. 5, and that the Vickers hardness of TiC (28-35 GPa) is higher than that of WC $(16-22 \mathrm{GPa})^{[4-5]}$. The literatures $^{[31-32]}$ also showed that the hardness of the WC-TiC cemented carbides increased with the reduction of the ratio of WC grain size and TiC grain size, and that the hardness of the additive had an important effect on the hardness of the composites. The effect specifically showed that the hardness of the composites would increase when the hardness of the additive was higher than that of the base material. Therefore, the hardness of the WC-TiC-TaC cemented carbides increased with the increase of $\mathrm{TiC}$ content. The value of the highest Vickers hardness was $19.81 \mathrm{GPa}$, which was higher than $18.53 \mathrm{GPa}$ reported by the literature ${ }^{[33]}$ and was close to $19.55 \mathrm{GPa}$ reported by the investigation ${ }^{[16]}$.

The flexural strength of these composites decreased gradually with the increase of TiC content in Fig. 6. As the TiC content was increased from $10 \mathrm{wt} \%$ to $25 \mathrm{wt} \%$, the 

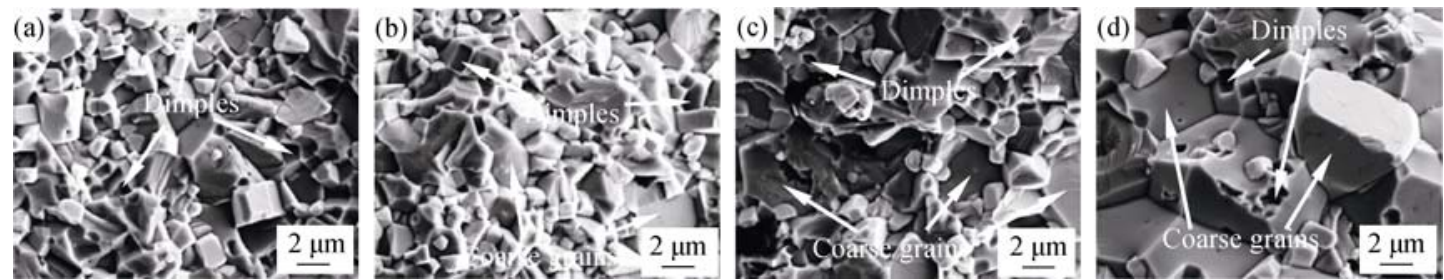

Fig. 5 Fracture morphologies of WC-TiC-TaC cemented carbides (a) WC-10wt\% TiC-TaC (S1), (b) WC-15wt\%TiC-TaC (S2), (c) WC-20wt\%TiC-TaC (S3), (d) WC-25wt\%TiC-TaC (S4)

flexural strength decreased from $(1123.24 \pm 24) \mathrm{MPa}$ to (672.25 \pm 35$) \mathrm{MPa}$. The main reason was that the number of the coarse grains in these cemented carbides increased progressively as the $\mathrm{TiC}$ content was increased from $10 \mathrm{wt} \%$ to $25 \mathrm{wt} \%$ in Fig. 5, which was consistent with the result of the literature ${ }^{[34]}$ and which led to the decline of the flexural strength. The further reason was that the grain size had an obvious influence on the flexural strength. The relationship between the flexural strength and grain size was described mathematically by the Hall-Petch equation ${ }^{[35]}$ :

$$
\sigma_{\mathrm{y}}=\sigma_{0}+\frac{k_{\mathrm{y}}}{\sqrt{d}}
$$

Where $\sigma_{\mathrm{y}}$ is the yield stress (the flexural strength), $\sigma_{0}$ is a materials constant for the starting stress for dislocation movement (or the resistance of the lattice to dislocation motion), $k_{\mathrm{y}}$ is the strengthening coefficient (a constant specific to each material), and $d$ is the average grain diameter (the average grain size). This equation reveals thatreducing the grain size will cause the material to become

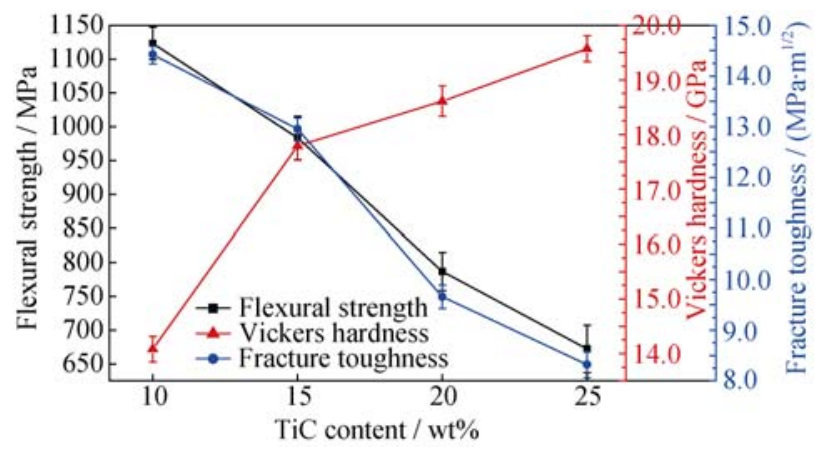

Fig. 6 Influence of $\mathrm{TiC}$ content on mechanical properties of WC-TiC-TaC cemented carbides

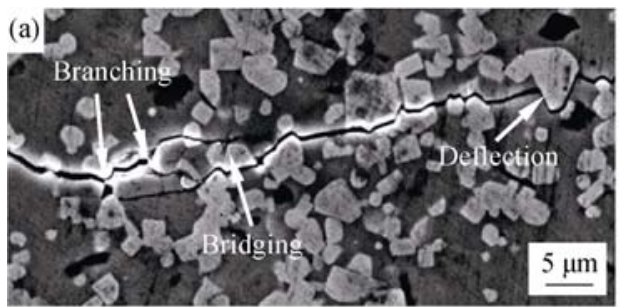

stronger. Therefore, the flexural strength of these composites would decrease when the average grain size was increased. In addition, grain size reduction was also a means of increasing the toughness of the material.

In Fig. 6, the fracture toughness decreased from (14.42 \pm $0.18) \mathrm{MPa} \cdot \mathrm{m}^{1 / 2}$ to $(8.32 \pm 0.26) \mathrm{MPa} \cdot \mathrm{m}^{1 / 2}$ when the $\mathrm{TiC}$ content was increased from $10 \mathrm{wt} \%$ to $25 \mathrm{wt} \%$. The value of the highest fracture toughness was $14.60 \mathrm{MPa} \cdot \mathrm{m}^{1 / 2}$, which was higher than $12.02 \mathrm{MPa} \cdot \mathrm{m}^{1 / 2}$ reported by the literature ${ }^{[16]}$. In general, the fine grains were propitious to enhance the fracture toughness while the coarse grains were adverse to the improvement of the fracture toughness. Besides, the toughness dimples in Fig. 5 were advantageous to the enhancement of the fracture toughness. The more dimples there were in the cemented carbide, the higher fracture toughness the cemented carbide $\mathrm{had}^{[36]}$. In order to further analyze the reason, the toughening mechanisms that operated in WC-TiC-TaC cemented carbides were presented in Fig. 7 which showed crack propagation paths of $\mathrm{WC}-10 \mathrm{wt} \% \mathrm{TiC}-\mathrm{TaC}(\mathrm{S} 1)$ cemented carbide and WC-25wt\%TiC-TaC (S4) cemented carbide. The sample of S1 had more fine WC grains than the sample of S4 in Fig. 7. The fine grains could increase the number of crack deflection that would consume much fracture energy and led to the fine-grain toughening. The sample of S1 was toughened by a lot of fine WC grains besides crack deflection, crack branching and bridging in Fig. 7(a), while the sample of S4 was toughened by crack deflection, crack branching and bridging in Fig. 7(b). Therefore, the high fracture toughness of the sample of S1 was due to an intensive coupled mechanism of the fine grains, crack deflection, crack branching, crack bridging and toughness dimples.

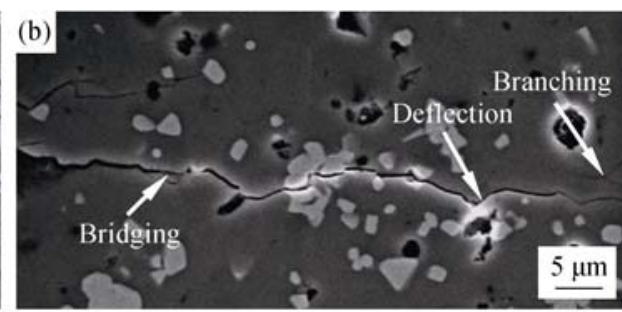

Fig. 7 Crack propagation paths of WC-TiC-TaC cemented carbides (a)WC-10wt\% TiC-TaC (S1); (b) WC-25wt\%TiC-TaC (S4) 


\section{Conclusions}

WC-TiC-TaC cemented carbides were fabricated by hot-pressed sintering at $1600^{\circ} \mathrm{C}$. Effects of TiC content on the microstructure and mechanical properties of these cemented carbides were investigated. When TiC content was increased from $10 \mathrm{wt} \%$ to $25 \mathrm{wt} \%$, both the average grain size and the Vickers hardness increased progressively, but both flexural strength and fracture toughness decreased gradually. The increase of Vickers hardness was attributed to the increase of TiC content and the higher hardness of TiC than that of WC. The value of the highest Vickers hardness was $19.81 \mathrm{GPa}$. The highest flexural strength (1147.24 MPa) was ascribed to the fine and homogeneous grains and the highest fracture toughness $\left(14.60 \mathrm{MPa} \cdot \mathrm{m}^{1 / 2}\right)$ was due to the intensive coupled mechanism of the fine-grain toughening, crack deflection, crack branching, crack bridging and toughness dimples.

\section{References:}

[1] UPADHYAYA G S. Materials science of cemented carbides - an overview. Mater. Des., 2001, 22: 483-489.

[2] MOUSTAFA S F, ABDEL-HAMID Z, OSAMA G, et al. Hussien, Synthesis of WC hard materials using coated powders. Adv. Powder Technol., 2011, 22: 596-601.

[3] LIN N, WU C H, HE Y H, et al. Effect of Mo and Co additions on the microstructure and properties of WC-TiC-Ni cemented carbides. Int. J. Refract. Met. Hard Mater., 2012, 30: 107-113.

[4] KIM HWAN-CHEOL, PARK HYUN-KUK, JEONG IN-KYOON, et al. Sintering of binderless $\mathrm{WC}-\mathrm{Mo}_{2} \mathrm{C}$ hard materials by rapid sintering process. Ceram. Int., 2008, 34: 1419-1423.

[5] RAJABI A, GHAZALI M J, DAUD A R. Chemical composition, microstructure and sintering temperature modifications on mechanical properties of TiC-based cermet - a review. Mater. Des., 2015, 67: 95-106.

[6] MILL B. Recent developments in cutting tool materials. J. Mater. Process Technol., 1996, 56: 16-23.

[7] YANG XUEFENG, WANG SHOUREN, YANG LIYING, et al. Research on the wear behaviors of WC- $8 \mathrm{Co}$ and $\mathrm{Al}_{2} \mathrm{O}_{3}$-TiC conical dies. J. Inorg. Mater, 2012, 27(8): 876-882.

[8] YAN KE, WANG YATAI, ZHU YONGSHENG, et al. Investigation on heat dissipation characteristic of ball bearing cage and inside cavity at ultra high rotation speed. Tribol. Int., 2016, 93: 470-481.

[9] XIONG JI, GUO ZHIXING, YANG MEI, et al. Tool life and wear of WC-TiC-Co ultrafine cemented carbide during dry cutting of AISI H13 steel. Ceram. Int., 2013, 39: 337-346.
[10] ZHAO JUN, YUAN XUNLIANG, ZHOU YONGHUI. Cutting performance and failure mechanisms of an $\mathrm{Al}_{2} \mathrm{O}_{3} / \mathrm{WC} / \mathrm{TiC}$ micronano-composite ceramic tool. Int. J. Refract. Met. Hard Mater, 2010, 28: 330-337.

[11] MAHMOODAN M, ALIAKBARZADEH H, GHOLAMIPOUR R. Sintering of WC-10\% Co nano powders containing TaC and VC grain growth inhibitors. Trans. Nonferrous Metals Soc. China, 2011, 21: 1080-1084.

[12] OUYANG CHENXIN, ZHU SHIGEN, QU HAIXIA. VC and $\mathrm{Cr}_{3} \mathrm{C}_{2}$ doped WC-MgO compacts prepared by hot-pressing sintering. Mater. Des., 2012, 40: 550-555.

[13] GENGA R M, CORNISH L A, AKDOGAN G. Effect of $\mathrm{Mo}_{2} \mathrm{C}$ additions on the properties of SPS manufactured WC-TiC-Ni cemented carbides. Int. J. Refract. Met. Hard Mater., 2013, 41: $12-21$.

[14] XIONG JI, GUO ZHIXING, SHEN BAOLUO, et al. The effect of $\mathrm{WC}, \mathrm{Mo}_{2} \mathrm{C}, \mathrm{TaC}$ content on the microstructure and properties of ultra-fine $\mathrm{TiC}_{0.7} \mathrm{~N}_{0.3}$ cermet. Mater. Des., 2007, 28: 1689-1694.

[15] WU PENG, ZHENG YONG, ZHAO YONGLE, et al. Effect of TaC addition on the microstructures and mechanical properties of $\operatorname{Ti}(\mathrm{C}$, N)-based cermets. Mater. Des., 2010, 31: 3537-3541.

[16] GENGA R M, AKDOGAN G, WeStraAdT J E, et al. Microstructure and material properties of PECS manufactured WC-NbC-Co and WC-TiC-Ni cemented carbides. Int. J. Refract. Met. Hard Mater., 2015, 49: 240-248.

[17] PIRSO J, VILJUS M, LETUNOVITŠ S. Friction and dry sliding wear behavior of cermets. Wear, 2006, 260: 815-824.

[18] ZOU BIN, HUANG CHUANZHEN, SONG JINPENG, et al. Effects of sintering processes on mechanical properties and microstructure of $\mathrm{TiB}_{2}-\mathrm{TiC}+8 \mathrm{wt} \%$ nano-Ni composite ceramic cutting tool material. Mater. Sci. Eng. A, 2012, 540: 235-244.

[19] SUN PEIQIU, ZHU DEGUI, JIANG XIAOSONG, et al. Research on microstructures and properties of in-situ synthesis of $\mathrm{TiB}_{2}-\mathrm{TiC}_{0.8}$-SiC multiphase ceramics. J. Inorg. Mater, 2013, 28(4): 363-368.

[20] LIN NAN, HE YUEHUI, WU CHONGHU, et al. Influence of TiC additions on the corrosion behaviour of WC-Co hardmetals in alkaline solution. Int. J. Refract. Met. Hard Mater, 2014, 46: 52-57.

[21] YU YINHU, WANG TAO, ZHANG HONGMIN, et al. Low temperature combustion synthesis of TiC powder induced by PTFE. $J$. Inorg. Mater., 2015, 30(3): 272-276.

[22] YANG SHIE, LU ZHANLING, FAN ZHIQIN, et al. Highly adherent diamond film deposited onto WC-Co cemented. J. Inorg. Mater, 2005, 20(1): 235-238.

[23] FANG Z Z, WANG X, RYU T, et al. Synthesis, sintering, and mechanical properties of nanocrystalline cemented tungsten carbide-a 
review. Int. J. Refract. Met. Hard Mater., 2009, 27: 288-299.

[24] KONG D H, HE BS, LIN L H. Effect of chromium content on structure and properties of WC-based cemented carbide. Shanghai Nonfer. Metal, 2005, 26: 53-57.

[25] SHI KAI-HUA, ZHOU KE-CHAO, LI ZHI-YOU, et al. Effect of adding method of $\mathrm{Cr}$ on microstructure and properties of WC-9Ni-2Cr cemented carbides. Int. J. Refract. Met. Hard Mater, 2013, 38: 1-6.

[26] LINDAHL P, GUATAFSON P, ROLANDER U, et al. Microstructure of model cermets with high Mo or W content. Int. J. Refract. Met. Hard Mater., 1999, 17: 411-421.

[27] LIU N, XU Y D, LI Z H, et al. Influence of molybdenum addition on the microstructure and mechanical properties of TiC-based cermets with nano-TiN modification. Ceram. Int., 2003, 29: 919-925.

[28] KWON HANJUNG, SUH CHANG-YUL, KIM WONBAEK. Microstructure and mechanical properties of $(\mathrm{Ti}, \mathrm{W}) \mathrm{C}-\mathrm{Ni}$ cermet prepared using a nano-sized TiC-WC powder mixture. J. Alloy. Compd., 2015, 639: 21-26.

[29] CHENG ZHANG, JINPENG SONG, LONGKAI JIANG, et al. Fabrication and tribological properties of $\mathrm{WC}^{-\mathrm{TiB}_{2}}$ composite cutting tool materials under dry sliding condition. Tribol. Int., 2017, 109: $97-103$.
[30] SHON I J, JEONG I K, KO I Y, et al. Sintering behaviour and mechanical properties of $\mathrm{WC}-10 \mathrm{Co}, \mathrm{WC}-10 \mathrm{Ni}$ and $\mathrm{WC}-10 \mathrm{Fe}$ hardmaterials produced by high frequency induction heated sintering. Ceram. Int., 2009, 35: 339-344.

[31] LI YUXIN, BAI PEIKANG, WANG YAOMIN, et al. Effect of TiC content on $\mathrm{Ni} / \mathrm{TiC}$ composites by direct laser fabrication. Mater. Des., 2009, 30: 1409-1412.

[32] EE KYONG H, CHA SEUNG I, KIM BYUNG K, et al. Effect of $\mathrm{WC} / \mathrm{TiC}$ grain size ratio on microstructure and mechanical properties of WC-TiC-Co cemented carbides. Int. J. Refract. Met. Hard Mater, 2006, 24: 109-114.

[33] LI ANHAI, ZHAO JUN, WANG DONG, et al. Three-point bending fatigue behavior of WC-Co cemented carbides. Mater. Des., 2013, 45: 271-278.

[34] WANG JUN, LIU YING, ZHANG PING, et al. Effect of VC and nano-TiC addition on the microstructure and properties of micrometer grade $\mathrm{Ti}(\mathrm{CN})$-based cermets. Mater. Des., 2009, 30: 2222-2226

[35] NIELS HANSEN. Hall-Petch relation and boundary strengthening. Scripta Mater., 2004, 51: 801-806.

[36] SONG JINPENG, HUANG CHUANZHEN, ZOU BIN, et al. Microstructure and mechanical properties of $\mathrm{TiB}_{2}$ - TiC-WC composite ceramic tool materials. Mater. Des., 2012, 36: 69-74.

\title{
TiC 含量对 WC-TiC-TaC 硬质合金材料微观组织及 力学性能的影响
}

\author{
高姣姣，姜龙凯，宋金鹏，梁国星，安晶，谢俊彩，曹 䂞，吕明 \\ (太原理工大学 机械工程学院, 精密加工山西省重点实验室, 太原 030024)
}

\begin{abstract}
摘 要: 本研究采用真空热压烧结技术, 在 $1600^{\circ} \mathrm{C}$ 下制备了 WC-TiC-TaC 硬质合金材料, 研究了 $\mathrm{TiC}$ 含量对其微观组 织及力学性能的影响。结果表明, 随着 $\mathrm{TiC}$ 含量的增多, 硬质合金材料的晶粒显著增大。当 $\mathrm{TiC}$ 的含量从 $10 \mathrm{wt} \%$ 增 加到 $25 \mathrm{wt} \%$ 时，硬质合金材料的硬度逐渐增大，最高可达 $19.81 \mathrm{GPa}$, 这是由于 $\mathrm{TiC}$ 的硬度高于基体 $\mathrm{WC}$ 的硬度; 与此 同时, 硬质合金材料的抗弯强度和断裂韧度逐渐减小。当 $\mathrm{TiC}$ 的含量为 $10 \mathrm{wt} \%$ 时, 材料的抗弯强度有最大值, 其值为 1147.24 MPa, 这是由于在材料内部形成了均匀、细小的晶粒组织; 在此含量下, 复合材料的增㓞机理为细晶增韧、裂 纹偏转、裂纹分支、裂纹桥接和㓞窝增韧, 其断裂韧度有最大值, 为 $14.60 \mathrm{MPa} \cdot \mathrm{m}^{1 / 2}$ 。
\end{abstract}

关 键 词: WC-TiC-TaC 硬质合金; 热压烧结; 微观结构; 力学性能

中图分类号: TB333; TG711 文献标识码: A 